\section{Prof. Edoardo Maragliano}

Prof. Edoardo Maragltano, the famous Italian physician, whose death recently occurred in his ninety-first year, was born at Genoa on June 1, 1849. $\mathrm{He}$ received his medical education at Naples, where his principal teachers were Salvatore Tommasi and Arnaldo Cantani, and qualified in 1870 with a thesis "of exceptional merit" on some diseases of the nerve centres. He started his career by being assistant to Prof. Enrico de Renzi at Naples for a few years, and then became lecturer in general pathology at Genoa from 1877 to 1881 . He was then elected professor of clinical medicine at Genoa, and held this post for forty-three years.

Maragliano succeeded in making his clinic at Genoa one of the most celebrated in Italy, and it was attended by practitioners from all parts of the country and abroad. Though he always subordinated laboratory examinations to clinical observation, he established a number of laboratories in connexion with his clinic to deal with the various problems connected with clinical medicine. His excellence as a teacher is shown by the fact that eight of his pupils afterwards obtained professorial chairs in various Italian universities.

Maragliano's writings ranged over all fields of internal medicine, including pneumococcal infections, cholera, and disorders of the blood and heart, but the disease in which he was most interested was pulmonary tuberculosis, and particularly prevention of the disease by a vaccine containing dead bacilli. Although the value of this method has not been proved, he did good work in conducting an active campaign against tuberculosis in Italy and he was largely responsible for a decline in its prevalence.

For seven years Maragliano was president of the Medical Faculty of Genoa and for more than ten years rector. In 1900 he was elected senator of Italy. His other activities consisted in the foundation of the Genoa Academy and an Italian Society of Internal Medicine in conjunction with Cantani and Bacelli, as well as of a post-graduate school for tuberculosis at Genoa which was attended by numerous practitioners from all parts of Italy. $\mathrm{He}$ was also founder of Archivio Italiano di Clinica Medica (1893), Annali dell' Instituto Maragliano per lo Studio e la Cura della Tubercolosi (1904) and Archividi Biologia (1924). During the War of 1914-18, in which he was given the rank of major-general, he was appointed director of the military clinic at Padua. J. D. Rolleston.

\section{Mr. W. S. Furneaux}

MANY a school-boy of forty years ago and many younger school-boys and former pupils will be sorry to hear of the death of W. S. Furneaux. He had the knack of writing just the sort of succinct and wellillustrated practical book which stimulated the young collector to hunt for spoils and afterwards to pore over the naming of them; and his publishers aided and abetted with that profusion of coloured plates which added attractiveness to utility. "The Outdoor World" (1893), one of the best of the series, was followed by accounts of "Life in Ponds and Streams" (1896), "The Sea Shore" (1903), and "Field and Woodland Plants" (1909), and these and his other works, such as "British Butterflies and Moths" (1894), must have opened up new worlds for young naturalists of two generations. It says something for their quality that they are still amongst the best of British books for their purpose.

Furneaux was born at Devonport in 1855, and was educated at Cheltenham College. Fventually he came to London, where he taught science successfully and with appreciation for many years, first as lecturer at the Pupil Teachers' Training Centre and principal of the Science and Art Evening Institute at Peckham, and later as lecturer in the Teachers' Day Training College at Islington. He retired in 1913 and settled in Felbridge, Sussex, and there his own love of Nature was exercised in the skilful and enthusiastic way in which during the course of years he transformed a bare meadow into a secluded woodland retreat.

He died on April 9, 1940, in his eighty-fifth year. J. RITCHIE.

\section{Dr. W. E. Sumpner}

THE death took place on May 8 of Dr. W. E. Sumpner, principal of the Birmingham Technical College during 1895-1930, in his seventy-sixth year.

He was appointed when the College (or School as it was originally called) was only four years old, and it was owing to his work and vision that it became such an important institution in this great industrial centre.

Sumpner was primarily a physicist and electrical engineer, and he was well known in scientific circles. In his early days he was connected with the City Guilds of London. In 1885 he took first-class honours in both mathematics and physics, and four years later he took the London D.Sc. He was then appointed fellow of University College, London, and fellow of the City and Guilds Institute. He was also fellow of the Physical Society, serving as vice-president for a time. For some of us in Birmingham perhaps he was best known and regarded as the genial president of a small scientific symposium known as the $R^{3}$, founded originally by the late Prof. Poynting, of the University of Birmingham, for those teaching science in the city. He married in 1901 Miss Lucy Weekes, who survives him with a son and a daughter.

J. H. Reynotds.

WE regret to announce the following deaths :

Prof. W. Blackadder, Jackson professor of engineering in the University of Aberdeen, on May 14, aged sixty-one.

Mr. E. R. Gunther, zoologist to the "Discovery" Committee, aged thirty-seven.

Prof. J. H. Muirhead, F.B.A., emeritús professor of philosophy in the University of Birmingham, on May 24, aged eighty-five. 